\title{
Editorial: Science and Applications of Coastal Remote Sensing
}

\author{
Kevin R. Turpie ${ }^{1 *}$, Steven G. Ackleson ${ }^{2}$, Kristin B. Byrd ${ }^{3}$ and Tiffany A. H. Moisan ${ }^{4 t}$ \\ ${ }^{1}$ Joint Center for Earth Systems Technology (JCET), University of Maryland, Baltimore, MD, United States, ${ }^{2}$ United States \\ Naval Research Laboratory, Washington, DC, United States, ${ }^{3}$ Western Geographic Science Center, United States Geological \\ Survey, Moffett Field, CA, United States, ${ }^{4}$ Wallops Flight Facility, NASA, Accomack County, VA, United States
}

Keywords: remote sensing, coastal water areas, marine ecosystems, coastal processes, turbid and shallow water

\section{Editorial on the Research Topic}

\section{Science and Applications of Coastal Remote Sensing}

The Earth has been aptly described as a coastal planet (Martínez et al., 2007). The coastal zone, defined as land where proximity to the coast is $<100 \mathrm{~km}$ and elevation is $<10 \mathrm{~m}$ above sea level, is a linear interface sprawling the Earth's surface between the planet's water bodies and land masses, with a length over 1.6 million kilometers. This significant feature of the Earth's surface is so long that it would wrap around the equator 402 times (Martínez et al., 2007) or stretch to the Moon and back twice. Although the coastal ocean spans $8 \%$ of the global ocean surface area (Cracknell, 1999), it accounts for $14-30 \%$ of the total marine organic matter (Gattuso et al., 1998). Coastal oceans, defined as ocean areas between the shore and the continental shelf edge, and associated coastal environments are on the front lines of a warming climate. A warming atmosphere driven by a rising carbon dioxide concentration, the annual average of which is now approaching $420 \mathrm{ppm}$ (https://www.esrl.noaa.gov), is driving sea level rise and possibly changes in coastal hydrology,

\section{OPEN ACCESS}

Edited and reviewed by: Marta Marcos,

University of the Balearic Islands, Spain

*Correspondence: Kevin R. Turpie

kturpie@umbc.edu

${ }^{\dagger}$ Deceased

Specialty section:

This article was submitted to

Coastal Ocean Processes,

a section of the journal

Frontiers in Marine Science

Received: 13 December 2020 Accepted: 01 February 2021

Published: 06 April 2021

Citation:

Turpie KR, Ackleson SG, Byrd KB and Moisan TAH (2021) Editorial: Science and Applications of Coastal Remote Sensing. Front. Mar. Sci. 8:641029. doi: 10.3389/fmars.2021.641029 currents and weather. Sea level rise due to melting glaciers and ice caps threaten inundation of coastal communities (Vitousek et al., 2017) as well as increased coastal erosion (Zhang et al., 2004), and warming ocean waters are expected to enhance the severity of tropical cyclones (Sobel et al., 2016). Disruptions in marine ecosystem biodiversity have been documented as tropical species shift poleward in response to warming trends (Pinsky et al., 2013) and coral reefs undergo mass bleaching (Heron et al., 2017).

Added to climate factors are the stresses imposed by growing coastal human populations on the marine services that they require to survive and thrive. Currently, $27 \%$ of the global population lives within the coastal zone (Kummu et al., 2016). This population is expected to nearly double by mid-century (Neumann et al., 2015), which will increase stressors on this changing coastal environment. Human dependency and exploitation of coastal resources has produced increasingly dramatic changes to coastal and inland aquatic habitats in the last 100 years (Turpie et al., 2017). Presently, the global per capita consumption of seafood represents $6 \%$ of all animal protein and is the most highly traded international food commodity (Smith et al., 2010). Aquaculture constitutes a growing portion of the consumer seafood supply. This trend is expected to continue with projected population growth and climate change (Wells et al., 2015).

In addition, stresses on coastal aquatic habitats have resulted in the emergence of many species of phytoplankton that are pernicious to both humans and aquatic ecosystems (Anderson et al., 2002). For example, aquaculture produces waste nutrients that fuel the formation of harmful algal blooms (HAB). The introduction of toxic HAB and the overgrowth of non-toxic or invasive phytoplankton species disrupt ecosystem functionality, and affect food and water resources. These changes stem largely from anthropogenic eutrophication (Glibert et al., 2005; Anderson, 2009). Excessive amounts of algae can decrease light penetration, negatively affecting water-column, and benthic photosynthesis. Some algal blooms can grow faster than natural grazers can consume them. 
TABLE 1 | List of eBook chapters.

\begin{tabular}{|c|c|c|}
\hline Authors & Title & DOI \\
\hline $\begin{array}{l}\text { S. Ackleson, J. P. Smith, L. M. Rodriguez, } \\
\text { W. J. Moses, and B. J. Russell }\end{array}$ & Autonomous Coral Reef Survey in Support of Remote Sensing & https://doi.org/10.3389/fmars.2017.00325 \\
\hline D. Chapple and I. Dronova & $\begin{array}{l}\text { Vegetation Development in a Tidal Marsh Restoration Project during a } \\
\text { Historic Drought: A Remote Sensing Approach }\end{array}$ & https://doi.org/10.3389/fmars.2017.00243 \\
\hline $\begin{array}{l}\text { J. Headley, B. J. Russell, K. Randolph, } \\
\text { M. Á. Pérez-Castro, R. M. } \\
\text { Vásquez-Elizondo, S. Enríquez, and } \\
\text { H. M. Dierssen }\end{array}$ & $\begin{array}{l}\text { Remote Sensing of Seagrass Leaf Area Index and Species: The } \\
\text { Capability of a Model Inversion Method Assessed by Sensitivity Analysis } \\
\text { and Hyperspectral Data of Florida Bay }\end{array}$ & https://doi.org/10.3389/fmars.2017.00362 \\
\hline $\begin{array}{l}\text { W. Jiang, B. R. Knight, C. Cornelisen, } \\
\text { P. Barter, and R. Kudela }\end{array}$ & $\begin{array}{l}\text { Simplifying Regional Tuning of MODIS Algorithms for Monitoring } \\
\text { Chlorophyll-a in Coastal Waters }\end{array}$ & https://doi.org/10.3389/fmars.2017.00151 \\
\hline Z. Lee, S. Shang, and R. Stavn & $\begin{array}{l}\text { AOPs Are Not Additive: On the Biogeo-Optical Modeling of the Diffuse } \\
\text { Attenuation Coefficient }\end{array}$ & https://doi.org/10.3389/fmars.2018.00008 \\
\hline J. Lehrter and C. Le & $\begin{array}{l}\text { Satellite Derived Water Quality Observations Are Related to River } \\
\text { Discharge and Nitrogen Loads in Pensacola Bay, Florida }\end{array}$ & https://doi.org/10.3389/fmars.2017.00274 \\
\hline M. Marrari, A. R. Piola, and D. Valla & $\begin{array}{l}\text { Variability and } 20 \text {-Year Trends in Satellite-Derived Surface Chlorophyll } \\
\text { Concentrations in Large Marine Ecosystems around South and Western } \\
\text { Central America }\end{array}$ & https://doi.org/10.3389/fmars.2017.00372 \\
\hline $\begin{array}{l}\text { T. Moisan, K. M. Rufty, J. R. Moisan, and } \\
\text { M. A. Linkswiler }\end{array}$ & $\begin{array}{l}\text { Satellite Observations of Phytoplankton Functional Type Spatial } \\
\text { Distributions, Phenology, Diversity, and Ecotones }\end{array}$ & https://doi.org/10.3389/fmars.2017.00189 \\
\hline T. Moisan and B. G. Mitchell & $\begin{array}{l}\text { Modeling Net Growth of Phaeocystis antarctica Based on Physiological } \\
\text { and Optical Responses to Light and Temperature Co-limitation }\end{array}$ & https://doi.org/10.3389/fmars.2017.00437 \\
\hline $\begin{array}{l}\text { J. Ortiz, D. Avouris, S. Schiller, J. C. Luvall, } \\
\text { J. D. Lekki, R. P. Tokars, R. C. Anderson, } \\
\text { R. Shuchman, M. Sayers, and R. Becker }\end{array}$ & $\begin{array}{l}\text { Intercomparison of Approaches to the Empirical Line Method for } \\
\text { Vicarious Hyperspectral Reflectance Calibration }\end{array}$ & https://doi.org/10.3389/fmars.2017.00296 \\
\hline A. Reisinger, J. C. Gibeaut, and P. E. Tissot & $\begin{array}{l}\text { Estuarine Suspended Sediment Dynamics: Observations Derived from } \\
\text { over a Decade of Satellite Data }\end{array}$ & https://doi.org/10.3389/fmars.2017.00233 \\
\hline $\begin{array}{l}\text { J. Snyder, E. Boss, R. Weatherbee, } \\
\text { A. C. Thomas, D. Brady, and C. Newell }\end{array}$ & $\begin{array}{l}\text { Oyster Aquaculture Site Selection Using Landsat 8-Derived Sea Surface } \\
\text { Temperature, Turbidity, and Chlorophyll a }\end{array}$ & https://doi.org/10.3389/fmars.2017.00190 \\
\hline $\begin{array}{l}\text { A. Trembanis, A. L. Forrest, B. M. Keller, } \\
\text { and M. R. Patterson }\end{array}$ & $\begin{array}{l}\text { Mesophotic Coral Ecosystems: A Geoacoustically Derived Proxy for } \\
\text { Habitat and Relative Diversity for the Leeward Shelf of Bonaire, Dutch } \\
\text { Caribbean }\end{array}$ & https://doi.org/10.3389/fmars.2017.00051 \\
\hline $\begin{array}{l}\text { R. Trinh, C. G. Fichot, M. M. Gierach, B. } \\
\text { Holt, N. K. Malakar, G. Hulley, and J. Smith }\end{array}$ & $\begin{array}{l}\text { Application of Landsat } 8 \text { for Monitoring Impacts of Wastewater Discharge } \\
\text { on Coastal Water Quality }\end{array}$ & https://doi.org/10.3389/fmars.2017.00329 \\
\hline
\end{tabular}

When they die, the bloom sinks and decomposes, and the resulting bacterial respiration takes up dissolved oxygen, causing hypoxic, and anoxic "dead zones," which can devastate fisheries and benthic communities (Anderson et al., 2000; Rabalais et al., 2002).

To better understand the mounting ecological pressures on coastal environments, ecosystem scientists and natural resource managers have increasingly turned to remote sensing for timely and spatially coherent information. In response, Earth imaging sensor technologies aboard satellites and aircraft have advanced rapidly from multispectral systems offering a small number of broad, discontiguous spectral bands in the visible and infrared portions of the spectrum to imaging spectrometers with continuous, high-resolution coverage throughout the visible and near-infrared spectrum (VNIR), e.g., between $400 \mathrm{~nm}$ and $1 \mu \mathrm{m}$ and spectral bandwidth $<10 \mathrm{~nm}$. Such sensors are referred to as imaging spectrometers or hyperspectral imaging systems. The next generation of space-based Earth imagers, such as the U.S. National Aeronautics and Space Administration (NASA) Ocean Color Imager (OCI), a component of the Plankton, Aerosol, Cloud and ocean Ecosystem mission (PACE) (Gorman et al., 2019), and the NASA Surface Biology and
Geology (SBG) designated observable (National Academies of Sciences, 2018) and the Geosynchronous Littoral Imaging and Monitoring Radiometer (GLIMR) (National Aeronautics Space Administration, 2019), will serve to extend the heritage of global ocean color imagery and will be designed for hyperspectral coverage to address a wide range of societal problems. Coincident with the large, national, multi-community efforts, miniaturized systems are rapidly under development that may be deployed on small unmanned aerial vehicles controlled by a single research group or even an individual researcher. As such, they may more accurately be described as embedded systems because they are integral to specific, small-scale research and management efforts and would not exist were it not for those activities.

With the availability of more spectrally complex imagery, new algorithmic approaches have emerged to retrieve more useful information from the data. Advances in coastal remote sensing technology are well-documented in recent review articles (De Moraes Rudorff and Kampel, 2012; Duffy et al., 2013; BlondeauPatissier et al., 2014; Mouw et al., 2015; Palmer et al., 2015; Hedley et al., 2016; Werdell et al., 2018).

The lynchpin for any environmental remote sensing operation is the coincidental collection of high quality, in situ observations 
of direct relevance to the calibration and validation of imagebased products. This requirement is particularly challenging within coastal environments where the temporal and spatial correlation scales can be quite short (Hedley et al., 2012; Moses et al., 2016). Traditional methods of collecting in situ observations from floating platforms can be compromised by water depth, either by restricting access or causing re-suspension of bottom sediments. In applications to benthic cover, such as coral reef surveys, observations with SCUBA have proven effective for collecting high quality data, but operations are slow, laborious, expensive, and require a high level of specialized training. To address these problems, researchers have developed autonomous methods of collecting in situ observations (Moline et al., 2005; Ryan et al., 2010). Autonomous in situ survey systems offer key advantages over traditional methods including lower survey costs (excluding the initial infrastructure investment) and orders of magnitude more data with greater dimensionality and aerial coverage, often representing environmental conditions that would prohibit safe, human-based operations.

The purpose of this Frontiers in Marine Science eBook focuses on remote sensing of the coastal ocean is to provide a condensed forum to sample areas of notable technological advance. It provides a sample of such innovations and considerations contributed from the coastal remote sensing community. Given the a priori emphasis placed on environmental problems, the papers included in this eBook largely address processes, methods and technology pertaining to biological resources. The eBook is comprised of 14 chapters representing the work and thoughts of 62 authors (Table 1). Remote sensing technology covers multispectral to hyperspectral systems applied to environments ranging from wetlands to the pelagic ocean. Many of the papers include a large component of radiative transfer modeling and algorithm development and several of the papers address new autonomous methods to survey the coastal ocean in support of algorithm development, validation, and verification. One paper

\section{REFERENCES}

Anderson, D. M. (2009). Approaches to monitoring, control and management of harmful algal blooms (HABs). Ocean Coast. Manage. 52, 342-347. doi: 10.1016/j.ocecoaman.2009.04.006

Anderson, D. M., Glibert, P. M., Burkholder, J. M. (2002). Harmful algal blooms and eutrophication: nutrient sources, composition, and consequences. Estuaries 25, 704-726. doi: 10.1007/BF02804901

Anderson, D. M., Kaoru, Y., and White, A. W. (2000). Estimated Annual Economic Impacts from Harmful Algal Blooms (HABs) in the United States. No. WHOI-2000-11. Norman: National Oceanic and Atmospheric Administration, National Severe Storms Lab.

Blondeau-Patissier, D., Gower, J. F. R., Dekker, A. G., Phinn, S. R., and Brando, V. E. (2014). A review of ocean color remote sensing methods and statistical techniques for the detection, mapping and analysis of phytoplankton blooms in coastal and open oceans. Prog. Oceanogr. 123, 123-144. doi: 10.1016/j.pocean.2013.12.008

Cracknell, A. P. (1999). Remote sensing techniques in estuaries and coastal zones - an update. Int. J. Remote Sens. 19, 485-496.

De Moraes Rudorff, N., and Kampel, M. (2012). Orbital remote sensing of phytoplankton functional types: a new review. Int. J. Remote Sens. 33, 61967-61990. doi: 10.1080/01431161.2011.601343 explores the use of acoustic remote sensing to improve studies of coastal ecosystems. Papers address multiple coastal remote sensing themes and applications, including remote sensing of coastal ecosystems (coral reefs: Trembanis et al.; Ackleson et al.; tidal marsh: Chapple and Dronova; seagrass: Hedley et al.), water quality (Reisinger et al.; Jiang et al.; Snyder et al.; Lehrter and Le; Trinh et al.), phytoplankton abundance and diversity (Moisan et al.; Moisan and Mitchell; Marrari et al.), and improvements to calibration and radiative transfer modeling (Ortiz et al.; Lee et al.). Water quality papers address a range of topics including suspended sediments in estuaries (Reisinger et al.), eutrophication, as indicated by chlorophyll-a (Jiang et al.), aquaculture site selection (Snyder et al.), and effects of river discharge and nutrient loads (Lehrter and Le; Trinh et al.).

\section{DEDICATION}

This eBook is dedicated to our co-editor Dr. Tiffany Moisan, a well-regarded ocean color remote sensing scientist, who unexpectedly passed away during its preparation. Dr. Moisan was a dear friend, and upbeat and enthusiastic colleague and a scientist committed to the use of remote sensing to improve our understanding of marine microbiology and phytoplankton ecology. Tiffany was a strong supporter of coastal remote sensing science and applications and wanted this publication to provide her colleagues a forum to share and promote their most recent accomplishments. Let the chorus of our shared song continue with her memory. Dr. Moisan is survived by her loving family, including her husband, Dr. John Moisan, and her two daughters.

\section{AUTHOR CONTRIBUTIONS}

All authors have contributed in equal amounts to this manuscript. All authors contributed to the article and approved the submitted version.
Duffy, J. E., Amaral-Zettler, L. A., Fautin, D. G., Paulay, G., Rynerson, T. A., Sosik, H. M., et al. (2013). Envisioning a marine biodiversity observation network. BioScience 63, 350-361. doi: 10.1525/bio.2013.63.5.8

Gattuso, J. P., Frankignoulle, M. M., and Wollast, R. (1998). Carbon and carbonate metabolism in coastal aquatic ecosystems. Ann. Rev. Ecol. Sys. 29, 405-434. doi: 10.1146/annurev.scolsys.29.1.405

Glibert, P., Anderson, D., Gentein, P., Granéli, E., and Sellner, K. G. (2005). The global complex phenomena of harmful algal blooms. Oceanography 18, 136-147. doi: 10.5670/oceanog.2005.49

Gorman, E. T., Kubalak, D. A., Patel, D., Dress, A., Mott, D. B., Meister, G., et al. (2019). "The NASA Plankton, Aerosol, Cloud, ocean Ecosystem (PACE) mission: an emerging era of global, hyperspectral Earth system remote sensing," Proceedings Volume 11151, Sensors, Systems, and Next-Generation Satellites, Vol. 23 (Strasbourg: Palais de la Musique et des Congrés) 111510G. doi: $10.1117 / 12.2537146$

Hedley, J. D., Roelfsema, C. M., Chollett, I., Harborne, A. R., Heron, S. F., Weeks, S. J., et al. (2016). Remote sensing of coral reefs for monitoring and management: a review. Remote Sens. 8:118. doi: 10.3390/rs8020118

Hedley, J. D., Roelfsema, C. M., Phinn, S. R., and Mumby, P. J. (2012). Environmental and sensor limitations in optical remote sensing of coral reefs: Implications for monitoring and sensor design. Remote Sen. 4, 271-302. doi: $10.3390 / \mathrm{rs} 4010271$ 
Heron, S. F., Eakin, C. M., and Douvere, F. (2017). Impacts of Climate Change on World Heritage Coral Reefs: A First Scientific Assessment. Paris: UNESCO World Heritage Center, 12.

Kummu, M, de Moel, H., Salvucci, G., Viviroli, D., Ward, P. J., and Varis, O. (2016). Over the hills and further away from coast: global geospatial patterns of human and environment over the 20th-21st centuries. Environ. Res. Lett. 11:034010. doi: 10.1088/1748-9326/11/3/034010

Martínez, M. L., Intralawan, A., Vázquez, G., Pérez-Maqueo, O., Sutton, P., Landgrave, R. (2007). The coasts of our world: Ecological, economic and social importance. Ecol. Econ. 63, 254-272. doi: 10.1016/j.ecolecon.2006.10.022

Moline, M. A., Blackwell, S. M., van Alt, C., Allen, B., Austin, T., Case, J., et al. (2005). Remote environmental monitoring units: an autonomous vehicle for characterizing coastal environments. J. Atmos. Ocean. Tech. 22:1797-1808. doi: 10.1175/JTECH1809.1

Moses, W. J., Ackleson, S. G., Hair, J. W., Hostetler, C. A., and Miller, W. D. (2016). Spatial scales of optical variability in the coastal ocean: Implications for remote sensing and in situ sampling. J. Geophys. Res. Oceans 121, 4194-4208. doi: 10.1002/2016JC011767

Mouw, C. B., Greb, S., Aurin, D., DeGiacomo, P. M., Lee, Z., Twardowski, M., et al. (2015). Aquatic color radiometry remote sensing of coastal and inland waters: Challenges and recommendations for future satellite missions. Remote Sens. Envirion. 160, 15-30. doi: 10.1016/j.rse.2015.02.001

National Academies of Sciences, Engineering, and Medicine (2018). Thriving on Our Changing Planet: A Decadal Strategy for Earth Observation from Space. Washington, DC: The National Academies Press. doi: 10.17226/24938

National Aeronautics and Space Administration (2019). NASA Targets Coastal Ecosystems with New Space Sensor. ed K. Northon. NASA Press Release written by Felicia Chou. Available online at: https://www.nasa.gov/press-release/ nasa-targets-coastal-ecosystems-with-new-space-sensor (accesssed August 1, 2019).

Neumann, B., Vafeidis, A. T., Zimmermann, J., and Nicholis, R. J. (2015). Future coastal population growth and exposure to sea-level rise and coastal flooding - a global assessment. PLoS ONE 10:e0118571. doi: 10.1371/journal.pone.0118571

Palmer, S. C. J., Kutser, T., and Hunter, P. D. (2015). Remote sensing of inland waters: challenges, progress, and future directions. Remote Sens. Environ. 157, 1-8. doi: 10.1016/j.rse.2014.09.021

Pinsky, M. L., Worm, B., Fogarty, M. J., Sarmiento, J. L., and Levin, S. A. (2013). Marine taxa track local climate velocities. Science 341, 1239-1242. doi: $10.1126 /$ science. 1239352

Rabalais, N. N., Turner, R. E., and Wiseman, W. J. (2002). Gulf of Mexico Hypoxia, A.K.A. "The Dead Zone". Ann. Rev. Ecol. Syst. 33, 235-263. doi: 10.1146/annurev.ecolsys.33.010802.150513
Ryan, J. P., Johnson, S. B., Sherman, A., Rajan, K., Py, F., Thomas, H., et al. (2010). Mobile autonomous process sampling within coastal ocean observing systems. Limnol. Oceanogr. Meth. 8, 394-402. doi: 10.4319/lom.201 0.8 .394

Smith, M. D., Roheim, C. A., Crowder, L. B., Halpern, B. S., Turnipseed, M., Anderson, J. L., et al. (2010). Sustainability and global seafood. Science 327, 784-786. doi: 10.1126/science. 1185345

Sobel, A. H., Camargo, S., J., Hall, T., M., C.-Lee, Y., Tippett, M., K., and Wing, A., A. (2016). Human influence on tropical cyclone intensity. Science 353:242-246. doi: 10.1126/science.aaf6574

Turpie, K. R., Ackleson, S., Bell, T., Dierssen, H. M., Goodman, J., Green, R., et al. (2017). Spectroscopy for global observation of coastal and inland aquatic habitats. 2017 IEEE International Geoscience and Remote Sensing Symposium (IGARSS) (Fort Worth, TX), 3051-3054. doi: 10.1109/IGARSS.2017.81 27642

Vitousek, S., Barnard, P. L., Fletcher, C. H., Frazer, N., Erikson, L., and Storlazzi, C. D. (2017). Doubling of coastal flooding frequency within decades due to sea-level rise. Sci. Rep. 7:1399. doi: 10.1038/s41598-01701362-7

Wells, M. L., Trainer, V. L., Smayda, T. J., Karlson, B. S. O., Trick, C. G., Kudela, R. M., et al. (2015). Harmful algal blooms and climate change: Learning from the past and present to forecast the future. Harmful Algae 49, 68-93. doi: 10.1016/j.hal.2015.07.009

Werdell, P. J., McKinna, L. I. W., Boss, E., Ackleson, S. G., Craig, S. E., Gregg, W. W., et al. (2018). An overview of approaches and challenges for retrieving marine inherent optical properties from ocean color remote sensing. Prog. Oceanogr. 160, 186-212. doi: 10.1016/j.pocean.2018.01.001

Zhang, K., Douglas, B. C., and Leatherman, S. P. (2004). Global warming and coastal erosion. Clim. Change 64, 41-58. doi: 10.1023/B:CLIM.0000024690.32682.48

Conflict of Interest: The authors declare that the research was conducted in the absence of any commercial or financial relationships that could be construed as a potential conflict of interest.

Copyright (C) 2021 Turpie, Ackleson, Byrd and Moisan. This is an open-access article distributed under the terms of the Creative Commons Attribution License (CC BY). The use, distribution or reproduction in other forums is permitted, provided the original author(s) and the copyright owner(s) are credited and that the original publication in this journal is cited, in accordance with accepted academic practice. No use, distribution or reproduction is permitted which does not comply with these terms. 